\title{
Students' need on basic English grammar teaching material based on interactive multimedia: an innovative design
}

\author{
Yuli Tiarina $^{*}{ }^{*}$, Hermawati Syarif ${ }^{2}$, Jufrizal Jufrizal ${ }^{3}$, Yenni Rozimela ${ }^{4}$ \\ ${ }^{1234}$ Universitas Negeri Padang, Indonesia \\ *)Corresponding author, ”e-mail: yulitiarina@yahoo.co.id
}

\begin{abstract}
This study was meant to explorers students' need on grammar teaching material. It was based on interactive multimedia generated into an innovative model of grammar teaching material. This was a R\&D study with Gall and Borg model with the population consisting of students from English Department of Universitas Negeri Padang taking Basic English Grammar subject. Stratified sampling technique involving seventy eight students was used and data collection was through an open questionnaire. The results showed Basic English Grammar teaching material based on interactive multimedia was highly needed and students have different learning style. Besides, they have different interest in music, movies and colors with all of them own laptops. Further research to investigate the effectiveness of the model of Basic English Grammar teaching material based on interactive multimedia needs to be conducted.
\end{abstract}

Keywords: Grammar, teaching material, innovation, interactive multimedia

How to Cite: Tiarina, Y., Syarif, H., Jufrizal, J., \& Rozimela, Y. (2019). Students' Need on Basic English Grammar Teaching Material Based on Interactive Multimedia: An Innovative Design. COUNS-EDU: The International Journal of Counseling and Education, 4(1), 29-37. doi:http://dx.doi.org/10.23916/0020190419310

\section{Introduction}

Disruptive innovation, predicted by Cristensen in the 90s, has come true (Christensen, 2011; Ninio, 2019; Vanmassenhove, Du, \& Way, 2017; Widyasari, 2018) and now comes up the theory of disruptive innovation on education. As the name implies disruptive innovation is unruly for conventional lecturers reluctant to use technology in education. In this era, a lecturer has at least five roles. These include serving as an educator, demonstrator, motivator, facilitator, and evaluator/assessor, and sometimes a designer. A lecturer must not rely the teaching material on the books only or in printed form but rather must design other techniques utilizing technology. It is time for Grammar lecturers to rise up and keep pace with technological advancement (Arjulayana, 2018; Van Trijp, 2017).

A number of studies pointed out the use of technology such as multimedia in various method and media enhance maximum opportunities for an English grammar lecturer to improve students' content mastery and motivation. According to Mohamad (2009), students experienced with Internet-based grammar instruction (IBGI) made fewer errors on their essay when compared to tradional colleagues. Similarly, Naba'h (2012) with his experiment research established that students with computer assisted grammar teaching recorded higher scores. Furthermore, according to Chang \& Ling (2012) Cognitive motivational Model \& CALL increased students grammar mastery and reading comprehension. Parra (2016) articulated from his qualitative data that students and parents had high motivation to learn grammar through video podcast. Similarly, a study conducted by Saeedi \& Biri (2016) showed Animated Sitcoms managed to increase students' grammar mastery on conditional sentences and as well as their 
interest. Tell me more, another courseware, is useful for both teachers and students (Yunus, Hasyim, Embi, \& Lubis, 2010). A research done by Koehler, Thompson \& Phye (2011) developed grammar learning using multimedia program with embedded tracking.

None of the previous studies, however, discuss the use of multimedia in teaching materials, with all focusing on experimenting the method and media. Unquestionably, teaching materials are important component in curriculum. (Cunningsworth, 1995; Howard Chen, Sarah Cheng, \& Chirstine Yang, 2017) pointed out the role of materials in language teaching "as a resource for presentation resources; activities for learners practice and communicative interaction; for learners on grammar, vocabulary, pronunciation stimulation and ideas for classroom functions; self-directed learning or self acces work". Text books, recording, video and newspaper are basic materials for use (Krivochen, 2019; MacSwan, 2018; Tomlinson, 2011). According to Tomlinson (2011), materials development refers to anything carried out by writers, teachers or learners to provide sources of language input in ways which maximize the likelihood of intake. Basically, materials developers, including teachers, may bring pictures or advertisements in the classroom, compose a textbook, and design a student worksheet, read a poem or an article aloud. Naba'h (2012) recommended varying the methods according to students' need and interest. Teachers need to develop their own teaching material.

However, relying on text books do not guarantee the effectiveness of teaching and learning process (Herrington \& Herrington, 1998). Lecturers need teaching materials which promote visual, verbal and kinestetic learning (Turnbull \& Lawarence, 2002), to ensure the 'visual', 'audio' or 'kinestetic' students benefit from their presentation. They should provide immediate feedback (Becker, 2001), and offer flexibility of time which allows students to choose particular topics and how long they want to learn (Hartoyo, 2008). Moreover, they should offer an individual interactive learning program that is beneficial for both 'fast' and 'slow' learning students (Naba'h, 2012). These characteristic is not found in books sold in the market.for this reason, a teacher needs to develop teaching materials based on technology (Motteram, 2011) by considering students' needs (Holguin \& Morales, 2014). This will help improve the content, topics, the kind of exercises, instructions, and so forth. The material should reflect the students' need (Cunningsworth, 1995; Lodhi \& Akash, 2019; Xiang \& Liu, 2018).

Based on the above discussion, a study on designing Basic English Grammar teaching material based on interactive multimedia was needed. This research investigated students' need in developing English Basic Grammar teaching materials. It was supposed to produce a tentative or temporal innovative design for Basic English Grammar teaching material based on interactive multimedia.

\section{The Importance of Teaching Grammar}

Grammar is often defined as forms and rules, a correct definition but not entirely true. Grammar is not only a system of rules governing the conventional arrangement and relationship of words in a sentence or a description of the rules governing how a language's sentences are formed (Brown H. D., 2001; Budi Setiawan, 2018; Ibatova \& Ivanova, 2018; Thornbury, 1999). It is a system of lexicogrammatical patterns used to make meaning in appropriate ways (Larsen-Freeman, 2014, p. 258). Besides, Larsen-freeman (2014) highlights that grammar has three dimensions, structure or form, semantics or meaning, and use or pragmatic. This means it focuses on how to form meaningful sentences in appropriate context (Wennerstrom, 2017).

Since the emergence of communicative approach, many language practitioners think grammar is not necessary. Such individuals might be influenced by the zero-option principle by Rod Ellis and input hypothesis by Stephen Krashen (Brown H. D., 2001). However, they are insensible to what Skehan (1994, p. 175) said, that "grammar still has a role to play in language teaching, but not in a direct manner". Some studies have shown that grammar teaching contributes to student language performance (Burgess \& Etherington, 2002; Fatemipour \& Hemmati, 2015; Housen, Pierrard, \& Van Daele, 2005). According to Thornbury (1999), grammatical instruction should be given for several reasons. First, grammar teaching provides a guidance to language learners to produce unlimited numbers of sentences. Second, the teaching of grammar offers direct correction to sentences containing ambiguity of meaning. Third, grammar teaching helps learners avoid the fossilization of mistakes. Therefore, instead of asking whether to teach grammar, it is better to, as pointed by Brown (2001), find optimal condition for overt teaching of grammar. This brings us to the need of innovation. 


\section{COUNS-EDU}

\section{Technology and Multimedia}

Innovation is "an improvement; a change; something new that did not exist before, something new at a specific context; all of the above combined; any of the above, but only when successfully implemented" (Reinders, 2014). The definition implies to be innovative does not mean finding, discovering or creating something new, but instead doing something to improve the existing method, media or printed teaching material(Hariguna \& Akmal, 2019; Rasel, Saad Abdullah, \& Chakrabarty, 2019; Wang \& Zhou, 2019).

Developing teaching materials with interactive multimedia is an innovation. The teaching materials are not restricted to pieces of text. It include a variety of media; Static and animated texts, sound, voice, still graphics (photos, illustrations, diagrams, icons, maps, etc.), animated graphics, and video (Derewianka, 2014). Interactivity is another element of multimedia which allow users to determine their steps using the media. A tool helps the user navigate by clicking on the available links or selecting the menu (Collins, Hammond, \& Wellington, 1997; Mayer R. E., 2005). According to Moreno and Valdez in Jingjit (2015), multimedia learning refers to a scientific explanation using instructional media in the classroom. The implementation of multimedia learning promote meaningful erudition. This can be achieved if learning materials are delivered to students through various tools, and interactivity in student educative activities. Kalyuga (2009) states that in teaching, teachers should be able to create an effective learning environment using words and images to promote the learning process.

Quoted from Sudhata and Tegeh (2009), multimedia is divided into two categories,: linear and interactive. Linear multimedia is not equipped with any controller operated by the user but runs sequentially (sequentially), for example TV and movies. Contrastingly, interactive multimedia is equipped with user-operated controller and users choose what they want for the next process () (Huang, 2018; Phillips, 1997; Schwier \& Misanchuk, 1993; Wu, 2018).

There are several types of multimedia viewed from message delivery and feedback. Judging from the message attainment tool, (Chapman and Chapman in Sudatha and Tegeh 2009; Chen, Juan, \& Liang, 2018; Mohamadi Zenouzagh, 2018) divide multimedia into online and offline deliveries. The former network to deliver information from one computer to a computer or server machine that becomes the center of data storage to another network, either local within an organization or the internet. In contrast, offline delivery is multimedia stored using a removable storage or packing device, such as on DVD or CDROM. Judging from the type of feedback in computer programs, (Laurillard in Munir 2010; Jeong, 2018; Qian, 2018) mentions two types of feedback, intrinsic and extrinsic. The intrinsic is the resultant feedback caused by a natural action. In this case, the program provide question facilities with answers. Contrastingly, extrinsic is a feedback to the data entered into the program because it provides a search facility for a particular word. Additionally, for a multimedia program created as an interactive media, feedback facility is very important. Generally, results are expected to increase the motivation of learners. Without feedback, learners are unaware of the consequences of their actions and this cause doubts. The creation of a multimedia program should take into consideration appropriate feedback for its learning as it improves the level of creativity of learners.

\section{Method}

In principle, this study followed the steps of research and development (R\&D) from Gall, Gall and Borg (2003). However, in its implementation, the model was simplified and adapted to the needs in the field. The term simplification and adjustment is also called small scale model (Gall, Gall, \& Borg, 2003, p. 572). This small scale model is carried out in writing a dissertation which use limited research steps but does not reduce the essence of the model. Therefore, this study used 2 steps out of the total 10. These are preliminary research and information gathering and developing a form of the product. In step 1, the researcher reviewed and collected information on student needs and characteristics through a questionnaire validated by two grammar experts. The study was conducted at English Department of Universitas Negeri Padang using stratified sampling technique with four classes. The researcher took randomly $10 \%$ for each class and seventy eight students were involved. Open questionnaires were used to find the needs of students on Basic English Grammar teaching materials. This was based on interactive multimedia consisting of fourteen (14) statements about approach and organization of teaching material, and 5 open questions on the availability of personal computers or laptops, learning styles, preferred movie types, music/songs, and colors. The data on students' needs were referred to scoring or value criteria. 
Weight 1 was for not needed, 2 for fairly needed, 3 for needed and 4 very needed. To get the average level of need, each category was summed and divided by the number of students. Then, the average score for each item was converted and interpreted in 4 categories as in the table below.

Table 1. Criteria for Students' Need on Basic English Grammar Teaching Material based on Interactive Multimedia

\begin{tabular}{ccc}
\hline Number & Mean Score & Criteria \\
\hline $\mathbf{1}$ & $0.00-1.00$ & Not needed \\
$\mathbf{2}$ & $1.01-2.00$ & Fairly Needed \\
$\mathbf{3}$ & $2.01-3.00$ & Needed \\
$\mathbf{4}$ & $3.01-4.00$ & Very Needed \\
\hline
\end{tabular}

In step 2, teaching materials were developed using the basic components proposed by Tomlinson and Hannafin \& Peck. These were packed using the principle of developing multimedia-based teaching materials, applying eleven multimedia principles by Mayer and determining Phillips's documentation, navigation, and graphic designs. The researcher designed the initial model of teaching material by involving a web designer.

\section{Results and Discussions}

The findings will be derived into three parts.

\section{Student Needs Analysis on Teaching Material based on Interactive Multimedia}

The following was the result of students' need presented in numerical form and reinforced with description of suggestions. The aspect was the need for an approach and teaching material organization described in 14 statements. It explored the level of the students' needs on the importance of teaching materials, learning approaches, the importance of interactive multimedia, and the organization or composition of teaching materials. Table 2 shows the number of student needs on the importance of instructing materials, learning approaches, the importance of interactive multimedia, and the organization or composition of teaching materials.

Table 2. Students' Needs Analysis on Teaching Material based on Interactive Multimedia

\begin{tabular}{|c|c|c|c|}
\hline Number & Items & Score & Criteria \\
\hline 1 & $\begin{array}{l}\text { The needed of teaching material for Basic } \\
\text { Grammar. }\end{array}$ & 3.8 & Very needed \\
\hline 2 & Fun Basic Grammar teaching material & 3.5 & Very needed \\
\hline 3 & Direct learning grammar from lecturers & 3.4 & Very needed \\
\hline 4 & Learning grammar from interactive multimedia & 3.1 & Very Needed \\
\hline 5 & $\begin{array}{l}\text { The opening of Basic Grammar teaching } \\
\text { material through films, short stories, songs or } \\
\text { poets displayed through interactive multimedia }\end{array}$ & 3.2 & Very needed \\
\hline 6 & $\begin{array}{l}\text { Discussion on the films, short stories, songs or } \\
\text { poets displayed through interactive multimedia }\end{array}$ & 3.1 & Very needed \\
\hline 7 & Teaching grammar inductively & 3.4 & Very needed \\
\hline 8 & Teaching grammar deductively & 3.3 & Very needed \\
\hline 9 & Making students' own sentences & 3.3 & Very needed \\
\hline 10 & Contextual and communicative exercises & 3.1 & Very needed \\
\hline 11 & $\begin{array}{l}\text { Learning materials through interactive } \\
\text { multimedia independently }\end{array}$ & 2.6 & Needed \\
\hline 12 & $\begin{array}{l}\text { Time for independent study trough interactive } \\
\text { multimedia }\end{array}$ & 2.8 & Needed \\
\hline 13 & Direct feedback for exercises & 3.2 & Very needed \\
\hline 14 & Interactive grammar games & $3 . .3$ & Very needed \\
\hline
\end{tabular}




\section{COUNS-EDU}

Twelve of the 14 statement points were 'very needed' by students (scores 3.1 - 3.8). Basic Grammar teaching materials was also very needed (3.8). Basic Grammar teaching materials really needed (3.5) fun teaching materials. Therefore, in the next statement they really need (3.1) teaching materials that use multimedia. The above findings were supported by student suggestions for the development of teaching materials. Among 78 students, half (50\%) gave suggestions for teaching material to be more fun, varied and the lecturers not relying on textbooks, interesting, creative and innovative using interactive image, audio, video, power point and games. However, one student (1.3\%) in his suggestion wrote that multimedia is less effective for Basic Grammar courses and teaching materials should be presented directly. Besides, two other students (2.6\%) gave suggestions for teaching materials presented directly by lecturers or combined with multimedia and games. Associated with learning directly from lecturers, students also need multimedia (3.4). Therefore, students desperately need a good Grammar Basic teaching material learned directly from lecturers and through interactive multimedia.

For the organization of Basic Grammar teaching materials based on interactive multimedia, students need (3.2) teaching materials opened with movies, songs, short texts or poems. Furthermore, they are also in great need of (3.1) movies, songs, short stories or poems presented. For the learning approach, students really need both techniques, that is inductive (3.4) and deductive (3. 3). In the written suggestion, 21 students $(26.9 \%)$ needed a detailed explanation of the material and given examples. Thus the students desperately need teaching materials with a prelude in form of a film, song, short text or poetry discussed and used as a guide related to the material to be studied. The lecturer explains the concept by examples afterwards.

For assessment, students need (3.3) to make examples in their own language. One student (1.31\%) suggested that lecturers should involve them by asking them to make sentences in their own language. Moreover, they also need (3.1) contextual and communicative exercises urgently. Besides, they urgently need (3.2) exercises that directly provide feedback through interactive multimedia, and (3.3) fun gameshaped exercises. Two students $(2.62 \%)$ gave suggestions for lecturers to give feedback in order to find out whether the work done is correct or not. Three students (3.85\%) suggested that lecturers should be able to monitor the extent of their development and understanding of the grammar and five others $(6.41 \%)$ suggested giving training in form of games. Therefore, in assessment aspect, teaching materials should have a training component involving students actively, either by allowing them to make their own sentences or through games. Teaching materials should facilitate lecturers and students in giving and getting feedback in order to track progress or understanding of students.

For self-study needs, students' scores were 2.6 and 2.8 , indicating they need to study the materials independently through interactive multimedia, and have time to learn independently through it. From the written advice, only one student (1.31\%) suggested they should be given the opportunity to learn independently. Five others (6.41) stated in writing that they prefer to do assignments in the classroom rather than at home because they want direct guidance from lecturers.

\section{Facility and Characteristics of Students}

Almost all students (91\%) had laptops or personal computers for can use inside or outside the classroom. Two students $(2.6 \%)$ gave did not have laptops but took turns with their siblings while five others $(6.4 \%)$ did not have completely. Student learning style was divided into three visual, audio and kinestetik. More than half of the students (52.6\%) had visual learning styles while $28.2 \%$ of had audio learning styles and the rest (18\%) had a kinesthetic.

Students were given the freedom to write movies, music and color, more than one in each option. The favorite movies include comedy, drama, horror, humor, documentation, action, mystery and animation. The best music types were pop, jazz, rock, country, reggae, hiphop, EDM, R \& B and classic while favorite colors are blue, green, black, pink, red, white, gray, purple, brown, yellow, orange, and maroon.

\section{The Model of Teaching material for Basic English Grammar based on Interactive Multimedia}

Based on the above findings, the development of teaching materials needs to be developed with the following principles:

1. Basic Grammar teaching materials should encompass movies, songs, short stories or poems as an and examples of the use of grammar taught before described in detail by the lecturer. Learning sessions 
should start with presenting films, songs or asking the students to watch early enough. Literary work make teaching materials fun, interesting and have moral value (ATMACA \& GUNDAY, 2016; Hua \& $\mathrm{Li}, 2015$ ). This section is referred to as Time to Watch. To avoid the boredom, for example, a movie should be used at the start of the first lesson and a song on the next class. The movies, song or short stories should be taken from YouTube.

2. Movies, songs and or short stories should be discussed by students and lecturers. This is referred to as Time to Chat. After watching movies, listening to the song and or reading the short stories, answering some questions should follow.

3. The teachers' explanation is still needed by the students. The finding is in line with Deng \& Ling According to (2016) who stated that many learners still like deductive teaching and therefore there should be focus on the grammar being studied. Once the lecturer explains the material, examples of the use of grammar should be provided. This is referred to as Time to Focus. The content should be taken from trusted grammar website.

4. The exercises should be presented in form of sentences, paragraphs or stories as well as interactive games. This make teaching materials interesting, keep students active and improve their grammar mastery (Macrory, 2000; Raftery \& Santos, 2015; Smaldino, Russell, Heinich, \& Molenda, 2014). The exercises should be given both inside and outside the class. To make it more interesting, exercise in the class should be presented in interactive games. The students can play individually or classically. This is referred to as Time for Fun. The games should be taken from internet.

5. The exercises should be given immediate feedback either directly by the lecturer or from the interactive multimedia and immediate feedback should be provided (Becker, 2001). This is referred to as Time for Practice and should contain interactive task and exercises.

6. Teaching materials should be supplemented with tools students may learn independently. They should offer flexibility of time that allows the them to choose particular topics and how long they want to learn (Hartoyo, 2008). This section is referred to as Time for Tube. The students should learn at home by watching tutorial taken from YouTube independenly and choose what they want and when to watch.

7. The task and exercises should be fun. As the last section, there should be Time for Action, a closing task designed for students to produce what they learn and understand in written or oral forms. If the opening is a movie, the students' task is to articulate the missing utterances of the movie with the appropriate and accurate expression or sentence. If the opening is a song, they should write a lyric of the song focusing on the grammar they learn.

8. Most of the resources of the materials should be taken from the internet, website, and YouTube in order to make the materials authentic and technology based (Kervin \& Derewianka, 2011; Motteram, 2011).

A look at the findings of students' need analysis proves Grammar lecturers have to open their mind for techonology. One possible explanation is the students highly need teaching material based on multimedia interactive. What students need really reflects that students are native in technology and familiar with media social.

\section{Conclusions}

Understanding and identifying students' need is vital in developing fun and interesting teaching material. Students need teaching material suitable with their learning style, and music preferences. They need immediate feedback and flexibility of time which allows them to choose particular topics and how long they want to learn. Lecturers should design Interactice multimedia covering students' need. They need explanation from the lecturer and study independently at home. While learning, they need fun exercises and tasks and start the material with literary work. Besides, they need to generate the syntax of teaching material as time to watch, chat, focus, practise, have fun, and action. Further research on the effectiveness of the model of Basic English Grammar teaching material based on interactive multimedia needs to be conducted to provide recommendations for future study. 


\section{References}

Arjulayana. (2018). Non-English learners' needs in learning English as a foreign language. Asian EFL Journal, 20(4), 154-161. Retrieved from https://www.scopus.com/inward/record.uri?eid=2-s2.0$85063439759 \&$ partnerID $=40 \& \mathrm{md} 5=72245 \mathrm{e} 090112 \mathrm{f} 7 \mathrm{db} 5 \mathrm{ce} 705 \mathrm{f} 82 \mathrm{bcb} 0 \mathrm{~d} 52$

Atmaca, H., \& Gunday, R. (2016). Using literary text to teach grammar in foreign language classroom. Participatory Educational Research (PER)ISSN: 2148-6123, 127-133.

Becker, H. (2001). Pedagogical motivation for students computer use that lead to student engagement. Educational Technology, 19-43.

Brown, H. D. (2001). Teaching by principles (2nd ed). New York: Longman.

Budi Setiawan, A. (2018). English grammar on 2013 curriculum: The development of game based learning multimedia. MATEC Web of Conferences, 205. https://doi.org/10.1051/matecconf/201820500011

Burgess, J., \& Etherington, S. (2002). Focus on grammatical form: Explicit or implicit. System, 30(4).http://dx.doi.org/10.1016/S0346-251X(02)00048-9, 433-458.

Chang, M.-M., \& Lin, M.-C. (2012). Integrating cognitive-motivational strategies into multimedia-based English instruction for low-achivers. 22-15 Agustus EUROCALL. Gothenburg: Research-publishing.net.

Chen, J.-A., Juan, C.-F., \& Liang, J.-C. (2018). Exploring the relationships between EFL learners' choices of multimedia and their approaches to learning english. ICCE 2018 - 26th International Conference on Computers in Education, Workshop Proceedings, 97-103. Retrieved from https://www.scopus.com/inward/record.uri?eid=2-s2.0-

85060044813\&partnerID=40\&md5=5647e1c0ef476b2e7996f58b0ebdd1 f8

Christensen, C. M., Horn, M. B., \& Johnson, C. W. (2011). Disrupting Class: How Disruptive Innovation Will Change the Way the World Learns. New York: McGraw Hill.

Collins, J., Hammond, M., \& Wellington, J. (1997). Teaching and learning with multimedia. London: Routladge.

Cunningsworth, A. (1995). Choosing your coursebook. Oxford: Heinemann.

Deng, F., \& Lin, Y. (2016). A comparative study on beliefs of grammar teaching between high school English teachers and students in China. English Language Teaching. 9(8) URL: http://dx.doi.org/10.5539/elt.v9n8p1, 1-10.

Derewianka, B. (2014). Developing electronic materials for language teaching. In B. Tomlinson, Developing Materials for Language Teaching (pp. 199 - 218). London: Bloomsbury Academic.

Ellis, R. (2003). Task-based language learning and teaching. Oxford: Oxford University Press.

Fatemipour, H., \& Hemmati, S. (2015). Impact of consciousness-raising activities on young English language learners' grammar performance. English Language Teaching, 8(9)doi:10.5539/elt.v8n9p1 URL: http://dx.doi.org/10.5539/elt.v8n9p1, 1-10.

Gall, M. D., Gall, J. P., \& Borg, W. R. (2003). Educational research: An introduction. Ed.7th. Boston: Pearson Education.

Hariguna, T., \& Akmal. (2019). Assessing students' continuance intention in using multimedia online learning. Telkomnika (Telecommunication Computing Electronics and Control), 17(1), 187-193. https://doi.org/10.12928/TELKOMNIKA.v17i1.10328

Hartoyo, A. (2008). Individual differences in Computer-Assisted Language Learning (CALL) . Semarang: Universitas Negeri Semarang.

Herrington, J., \& Herrington, A. (1998). Authentic assessment and multimedia: How university responds to a model of authentic assessment. Higher Education Research and Development, 17(3), 305-322.

Holguin, B. R., \& Morales, J. A. (2014, October). Materials development in the Colombian context: Some considerations about its benefits and challenges. HOW: A Columbian Journal for Teaching of English, 21(2), 134-150.

Housen, A., Pierrard, M., \& Van Daele, S. (2005). Rule complexity and the efficacy of explicit grammar instruction. In A. Housen, \& M. Pierrard (Eds.) . Investigation in instructed language acquisitionAmsterdam: Mouton de Gruyter. http://dx.doi.org/10.1515/9783110197372, 235-269.

Howard Chen, H.-J., Sarah Cheng, H.-W., \& Chirstine Yang, T.-Y. (2017). Comparing grammar feedback provided by teachers with an automated writing evaluation system. English Teaching and Learning, 41(4), 99-131. https://doi.org/10.6330/ETL.2017.41.4.04

Hua, C., \& Li, B. (2015). Bringing Fun and Meaning into Grammar Learning: A Case Study of a Secondary-Level EFL Class in. Cogent Education, Vol. 2, No.1.

Huang, H. (2018). Computer multimedia aided word annotation for incidental vocabulary acquisition in english reading. Kuram ve Uygulamada Egitim Bilimleri, 18(6), 3417-3427. 
https://doi.org/10.12738/estp.2018.6.248

Ibatova, A. Z., \& Ivanova, N. L. (2018). Teaching English grammar to engineering students and improving its efficiency in the context of the educational program in Tyumen Industrial University. International Journal of Mechanical Engineering and Technology, 9(4), 1117-1125. Retrieved from https://www.scopus.com/inward/record.uri?eid=2-s2.0-

85046782869\&partnerID $=40 \&$ md5 $=05$ ea52a2b5720741b996eef843e $9 \mathrm{acbb}$

Jeong, K.-O. (2018). Developing efl learners' communicative competence through multimedia-assisted language learning. Journal of Theoretical and Applied Information Technology, 96(5), 1367-1376. Retrieved from https://www.scopus.com/inward/record.uri?eid=2-s2.085044238424\&partnerID $=40 \& \mathrm{md} 5=\mathrm{f} 2 \mathrm{c} 1 \mathrm{c} 6348419 \mathrm{f} 21252 \mathrm{dd} 922854 \mathrm{fcadd} 0$

Jingjit, M. (2015). The effects of multimedia learning on Thai primary pupils' achievement in size and depth of vocabulary knowledge. Journal of Education and Practice (Online), Vol. 6. No. 32, (http:// www.iiste.org), 72-81.

Kalyuga, S. (2009). Managing cognitive loading adaptive multimedia learning. Systemics, Cybernetics, and Informatics (Online), Vol. 7, No. 5 (http://www.iiisci.org), 16-21.

Kervin, L., \& Derewianka, B. (2011). New technology to support language learning. In B. Tomlinson, Materials Development in Language Teaching (pp. 328-350). Cambridge: Cambridge University Press.

Koehler, N. A., Thompson, A. D., \& Phye, G. D. (2011). A design study a multimedia instructional grammar program with embedded tracking. Instructional Science: An International Journal of the Learning Sciences, 39(6), 939-974.

Krivochen, D. G. (2019). On trans-derivational operations: generative semantics and tree adjoining grammar. Language Sciences, 74, 47-76. https://doi.org/10.1016/j.langsci.2019.04.002

Larsen-Freeman, D. (2014). "Teaching Grammar". In M. Celce-Murcia, D. M. Brinton, \& M. A. Snow, Teaching English as a second or foreign language (pp. 256-270). Boston: Heinle.

Lodhi, M. A., \& Akash, A. (2019). Identifying language learning gaps of ESL students at intermediate level in Pakistani colleges. Bellaterra Journal of Teaching and Learning Language and Literature, 12(1), 4464. https://doi.org/10.5565/rev/jt13.783

Lyashensko, M. (2016). Implementation of web-based technologies into teaching and learning practices in the university. International Journal of Information and Education Technology (Online), Vol. 6, No. 3, (http://www.ijet.org), 243-246.

Macrory, G. (2000). Learning to teach grammar in the Modern Foreign Language classroom and some implications for initial teacher education. Research in Education, 64, http://dx.doi.org/10.7227/RIE.64.1, $55-82$.

MacSwan, J. (2018). Academic English as standard language ideology: A renewed research agenda for asset-based language education. Language Teaching Research. https://doi.org/10.1177/1362168818777540

Mayer, R. E. (2001). Multimedia Learning. New York: Cambridge University Press.

Mayer, R. E. (2005). Introduction to multimedia learning. Dalam R. E. Mayer, The Cambridge Handbook of Multimedia Learning (hal. 1-16). Cambridge: Cambridge University Press.

Mohamad, F. (2009). Internert-based grammar instruction in the ESL classroom. International Journal of Pedagogies and Learning, Vol. 5, No.2, 34-48.

Mohamadi Zenouzagh, Z. (2018). Multidimensional analysis of efficacy of multimedia learning in development and sustained development of textuality in EFL writing performances. Education and Information Technologies, 23(6), 2969-2989. https://doi.org/10.1007/s10639-018-9754-y

Motteram, G. (2011). Developing language-learning materials with technology. In B. Tomlinson, Materials Development in Language Teaching. 2nd Edition (pp. 303-326). Cambridge: Cambridge University Press.

Munir. (2010). Kurikulum berbasis teknologi informasi dan teknologi. Bandung: Alfabeta.

Naba'h, A. M. (2012). The impact of computer assisted grammar teaching on EFL pupils' performance in Jordan. International Journal of Education and Development Using Information and Communication Technology, Vol.8, No. 1, 71-90

Ninio, A. (2019). Complement or adjunct? The syntactic principle English-speaking children learn when producing determiner-noun combinations in their early speech. First Language, 39(1), 33-44. https://doi.org/10.1177/0142723717729276

Parra, S. (2016). Use of student created video postcards to promoto language grammar acquisition in middle school. Florida: Unpublished Dissertation, ProQuest LLC, Nova Southern University. 


\section{COUNS-EDU}

Phillips, R. (1997). The developers' handbook to interactive multimedia. London: British Library.

Qian, Y. (2018). Application research of E-learning network teaching platform in college english reading teaching. Kuram ve Uygulamada Egitim Bilimleri, 18(5), 1819-1827. https://doi.org/10.12738/estp.2018.5.082

Raftery, B., \& Santos, J. (2015). Grammar games: A case for instructionist game models to enhance grammar awareness and acccuracy. Journal of Instructional Research, Vol.4. http//eric.ed.gov, 142-147.

Rasel, A. A., Saad Abdullah, M., \& Chakrabarty, A. (2019). Learning dictionary for higher secondary school textbook in Bangladesh. 2018 Joint 7th International Conference on Informatics, Electronics and Vision and 2nd International Conference on Imaging, Vision and Pattern Recognition, ICIEV-IVPR 2018, 334-337. https://doi.org/10.1109/ICIEV.2018.8641029

Reinders, H. (2014). Dipetik December 15, 2016, dari www.cambridge.org/discoveryreaders

Saeedi, Z., \& Biri, A. (2016). The application of techonology in teaching grammar to EFL learners: The role of animated sitcoms. Teaching English with Technology, Vo. 16, No. 2, 18-39.

Schwier, R. A., \& Misanchuk, E. R. (1993). Interactive multimedia instruction. New Jersey: Educational Technology Publications.

Skehan, P. (1994). "Second language acquisition strategies, interlanguage development and task based learning". In M. Bygate, A. Tonkyn, \& E. Williams, Grammar and the Language Teacher (pp. 175-200). New York: Prentice Hall.

Smaldino, S. E., Russell, J. D., Heinich, R., \& Molenda, M. (2014). Instructional Media and Teachnology for Learning. Ed.10th. New Jersey: Prentice Hall.

Sudhata, I. G., \& Tegeh, I. M. (2009). Dipetik March 12, 2017, dari http://test.elearningambarsrilestari.web.id/wp-content/uploads/2016/01/Desain-Multimedia.pdf.

Thornbury, S. (1999). How to teach grammar. Harlow: Pearson Longman.

Tomlinson, B. (2011). Materials development in language teaching. Dalam B. Tomlinson, Materials Development in Language Teaching, second Ed. (hal. 1-24). Cambridge: Cambridge University Press

Turnbull, M., \& Lawarence, G. (2002). Computers make sense according to brain research... But what do students think? Canadian Association of second Language Teacher.

Van Trijp, R. (2017). A computational construction grammar for English. AAAI Spring Symposium Technical Report, SS-17-01-, 266-273. $\quad$ Retrieved from https://www.scopus.com/inward/record.uri?eid=2-s2.085028703667\&partnerID=40\&md5=222530a8c625ad639ca1c189e036e 43f

Vanmassenhove, E., Du, J., \& Way, A. (2017). Investigating "aspect" in NMT and SMT: Translating the english simple past and present perfect. Computational Linguistics in the Netherlands Journal, 7, $109-127$. Retrieved from https://www.scopus.com/inward/record.uri?eid=2-s2.085032571980\&partnerID $=40 \& m d 5=286 f 4 a 73 c 3032 \mathrm{ca} 7 \mathrm{fd} 93266 \mathrm{~b} 36 \mathrm{f} 62 \mathrm{fa} 6$

Wang, Y., \& Zhou, H. (2019). Study on the network-based English phonetics teaching mode for Englishmajor students. International Journal of Emerging Technologies in Learning, 14(5), 165-175. https://doi.org/10.3991/ijet.v14i05.8277

Wennerstrom, A. (2017). Intonation and language learning. In The Routledge Handbook of Contemporary English Pronunciation (pp. 154-168). https://doi.org/10.4324/9781315145006

Widyasari, F. E. (2018). Musical intelligence based instructions to teach english to young learners. Asian ESP Journal, 14(3), 17-31. Retrieved from https://www.scopus.com/inward/record.uri?eid=2-s2.085056986801\&partnerID=40\&md5=7d05a7f90607402c5241a4fe8528ca19

$\mathrm{Wu}, \mathrm{B}$. (2018). Construction of ecological teaching model for college english course under the background of internet plus. Kuram ve Uygulamada Egitim Bilimleri, 18(6), 3515-3521. https://doi.org/10.12738/estp.2018.6.261

Xiang, D., \& Liu, C. (2018). The Semantics of MOOD and the Syntax of the Let's-construction in English: A Corpus-based Cardiff Grammar Approach. Australian Journal of Linguistics, 38(4), 549-585. https://doi.org/10.1080/07268602.2018.1510726

Yunus, M. M., Hasyim, H., Embi, M. d., \& Lubis, M. A. (2010). The utilization of ICT in the teaching and learning of English: TELL ME MORE. Procedia-Social and BehavioralSciences, 9, 685-691. 